\title{
Resignification of educational e-innovation to enhance opportunities for graduate employability in the context of new university degrees
}

\author{
Rosa María Torres Valdés ${ }^{1 \star}$ (), Alba Santa Soriano² $\mathbb{0}$, Carolina Lorenzo Álvarez ${ }^{3}$ \\ 'Department of Communication and Social Psychology, Faculty of Economics and Business, University of \\ Alicante, Spain \{rosa.torres@ua.es\} \\ ${ }^{2}$ Faculty of Philosophy and Letters, Service of Research Management and Technology Transfer, University of \\ Alicante, Spain \{alba.santa@ua.es\} \\ ${ }^{3}$ Faculty of Philosophy and Letters, University of Alicante, Spain \{cla@alu.ua.es\} \\ Received on 09 September 2017; revised on 18 October 2017; accepted on 18 October 2017; published on 15 January 2018
}

\begin{abstract}
This paper presents the findings of a training programme based on an Action-Research methodology that has been applied in two subjects of Event Organization, Protocol and Institutional Relations undergraduate and Master's degrees. Through a teaching methodology called «learning by doing», students are encouraged to understand, internalise and apply the potential of technology in this field of knowledge, by means of building their personal brand as a key for digital literacy and professional empowerment. Thus, firstly this work proposes a review of the use of technology in teaching, with the goal of resignifying the concept of educational e-innovation from a transdisciplinary approach, which promotes progress in education ranging from technological to social innovation (technological-education-cultural-relational). Then, both the specific features and activities designed to build the students' personal brands during the course as well as the research methodology applied to analyze the results are described. The methodology is based on a longitudinal "ex post-facto» approach through a panel sample survey. Finally, results demonstrate how this training programme has allowed graduates to improve their employability and career development opportunities from then on, encouraging active participation and self-directed learning. Initial conclusions encourage us to apply this experience to larger groups and new university degrees in the higher education context.
\end{abstract}

KEYWORDS: EDUCATIONAL INNOVATIONS, EMPLOYMENT OPPORTUNITIES, EDUCATIONAL TECHNOLOGY, TEACHING METHODS, PERSONAL BRANDING

\section{INTRODUCTION}

The new map of advanced degrees shows an emergence of professional profiles better suited to present times. This era is characterized by disruptive innovation, globalization and socio-economic uncertainty in the labor market (WEF, 2016), which requires novel relational and communicative strategies to cope

\footnotetext{
*To whom correspondence should be addressed:
}

Department of Communication and Social Psychology, Faculty of Economics and Business, University of Alicante, San Vicente del Raspeig Road, s/n, 03690 San Vicente del Raspeig, Alicante, Spain with this crucial challenge (USC, 2016). As such, new university degrees are emerging, such as Event Organization, Protocol and Institutional Relations (Campos \& Fuente, 2013), which provide professional specialization in this branch of knowledge (Herrero $\&$ Perelló, 2017). On the one hand, Protocol engages with normative elements in a process of coherent communication between the identity of the State and its public image (Otero, 2002). On the other, Event Organization is increasingly becoming relevant in the communication strategy of organizations (Mair \& Whitford, 2013), which is in turn crucial in the relations with stakeholders and the community (Richards, Marques, \& Mein, 2014) and quintessential in their territorial impact (Richards, 2017).

With regards to e-innovation in higher education and its resignification, it is important to reflect on students' training in three thinking dimensions: systemic (Avargil, Herscovitz, \& Dori, 2012), strategic (Asiya, Naaranoja, Kyotla, \& Kantola 2016) and dialogic (Hajhosseiny, 2012). These dimensions should sustain creative learning environments (Davies, Jindal, Collier, Digby, \& Hay, 2013) and turn students into competent professionals and entrepreneurs, with a critical and transdisciplinary vision, which in Morín's terms, father of complex thinking, can be considered a product of inadequacy "of disjoined, divided and partitioned wisdoms" (Morín, 1999, p. 16), which in addition constitutes an educational challenge of the reorganization of thinking and education.

A literature review in this respect shows a notable number of research efforts for educational innovation (Strongoli, 2014), which is greater today concerning the learning-technology bundle (OCDE, 2015). This research, focused on the exploration of the role of technology in teaching, has produced several proposals of application models in this area, amongst which the TPACK Model (Technological Pedagogical Content Knowledge) stands out. It was proposed by authors Mishra and Koehler (2006) for combining pedagogic, disciplinary and technological dimensions in the integration of Information and Communication Technologies (ICT) in the pedagogic methodology. Carlsson, Tayie, Jacquinot Delaunay and Pérez Tornero (2008), De Abreu, Mihailidis, 
Lee, Melki and McDougall (2017) and, specifically, López and Aguaded (2015) in communication, highlight the importance of educating in media autonomy as a strategy for emancipation, especially among the youth (Xuan \& Xioameng, 2015), digital natives according to Prensky (2001), for stimulating in them crucial professional competences in the digital era, such as digital and informational competence, critical thinking and participatory culture (EU, 2017; Gutiérrez \& Torrego, 2017; Mihailidis, 2015). The main goal, therefore, is to promote a holistic vision of digital technologies, with regards to which authors like Adell and Castañeda (2013) highlight the importance of having first a "compatible" pedagogic theory aligned with learning purposes, so that it is possible later on to decide which to use and how to use them in order to attain the expected goals. Incorporating them, additionally, constitutes an opportunity to improve students' motivation and increases employability among graduates, as results from recent experiences in higher education show, for instance in Tourism (Teixeira, Albino, \& Oom, 2015) and Social Innovation (Maxwell, Irwin, \& Bennet, 2015; Rivers, 2016).

Today, there is evidence of a wide range of acronyms referring to technologies in the communication and learning context. We may highlight the evolution of TIC-TAC-TEP (Spanish acronyms for Information and Communication Technologies - Technologies for Learning and Knowledge - Technologies for Empowering and Participation) (Reig, 2012; Sancho, 2008; Sardelich, 2012); or the evolution coined as TDIC-TDICE (Spanish acronyms for Digital Information and Communication Technologies - Digital Information, Communication and Expression Technologies), studied by De Andrade and Lacerda (2014). These present TDICE as an inclusive pedagogic and mediation space for teachers and students "to resignify new knowledge mediated by the community" (De Andrade \& Lacerda, 2014, p. 6). These present opportunities for the development of educational e-innovation, but as Moreno and Vera $(2012$, p. 2) suggest, "the opportunities are as wide as the level of competences and the user's objectives". They criticize the risk of doing useless things and falling into clichés which move away from good pedagogy. For this reason, tackling the challenge of educational e-innovation's resignification requires analyzing, in addition to its latent strengths, its limitations, such as the lack of moral and emotional intelligence or the incapability to mobilize commitments, as pointed out by these authors. Cano (2012) proposes rethinking the contribution of technology in higher education, so that students achieve skills for understanding, analysis, criticism, teamwork and, above all, unlearn and learn to learn, and refers to technological detoxification as a means to rethink the use of technologies in education in a balanced manner.

In the framework of educational processes Porta and Sarasa (2014, p. 293) observe and resignify theoretically, from a narrative inquiry in their study, what they refer to as "categories of good teaching", which according to the authors "involve, among other aspects, the personal knowledge of the teacher, their love for students and their tasks, the moral sights of their practices and the conception of teaching as a game that deserves to be addressed with seriousness". Namo (2005) suggests resignifying the role of the teacher, and proposes distinguishing between training teachers in digital technologies and placing the latter at the service of education. Abraham (2004) understands that the resignification of the educational process is based on understanding that teaching is not only an act of instruction, in the same way that learning is not only the student's responsibility, but rather both are closely related and, as Sobrino (2011) points out, the role of the teacher must be of an anchor. This discussion shows the need to "go beyond literacy and acquisition of basic arithmetic competences and focusing on learning environments in new learning approaches" (UNESCO, 2015, p. 3).

The new logics of e-innovation in higher education carries with it a critical vision of the system and the educational policies from a desire to improve and socialize innovation, and to increase opportunities for the improvement of the employability across graduates. Pineda (2002) proposed the resignification of reality under the light of technological innovation and, with regard to the formal educational system, presented a criticism on the risks of acritical incorporation of technological innovations, sometimes mass production and consumption oriented, and where the pedagogic essence faded away. Fernández, Cabreiro and Fernández (2010) prefer to speak about knowledge society, instead of information society, which prioritizes promoting the development of services and consumption; and Ricaurte (2016) underlines the importance of exploring novel pedagogies for an open and inclusive knowledge society. Here, an element for reflection emerges with regards to the approach to resignification that is proposed in this work, centered on differentiating between knowledge society focused on the social appropriation of knowledge and enabler of social innovation processes, and information society which becomes in itself a consumer good. As Aguaded and Tirado (2008, p. 75) suggest, "innovation must be understood as a process of didactic action based on reflection and constant evaluation of what has been experimented", a fact unaligned with the pace demanded by the current market.

This work is more related with the role of education in digital transformation than with the role that this transformation plays in education, since in the teaching-learning relationship the educational use of ICT does not in itself guarantee a change in learning. It only constitutes a set of mediating instruments according to Vigotsky (1988). There are many contributions to pedagogic paradigms developed in this direction, such as connectivism (Siemens, 2006), invisible learning (Cobo \& Moravec, 2011), the digital skills map (Ferrari, 2013), autonomous learning (Mitra, Kulkarni, \& Stanfield, 2016) and dialogic learning (Simpson, 2016). While the role of technology in education has been fundamental, it is also important to consider the role of good pedagogy in educational e-innovation. For this reason, it is necessary to resume proposals from the field of knowledge of Organizational Psychology, relevant for the goal that this work pursues. For example, López and Miró (2014) reflect on the extent to which the known Rosenthal and Hwathorne effects can contribute positively or negatively to teaching innovation, and claim that the decision about which teaching method to use in a subject is given in great deal by the beliefs of the teacher responsible for it, which could foster or hinder learning. In this same line, Mora (2013), in relation with neuroeducation, says that it is necessary to "evaluate and improve the preparation of the person who teaches, and help and facilitate the process of those who learn" (p. 25), and proposes to anticipate the "emotional blackout" (p. 65) which can occur when the learning process becomes tedious and hard. Indeed, emotions stimulate curiosity, which undoubtedly constitutes an important factor for learning. In the same way, it seems evident that without e-emotions there is no education (Forés, 2012). More recently, Cobo (2016) has suggested in a work entitled Pending Innovation, among others, three items which inspire this paper: How does education fit in these digital recalibrations of society? How to find meaning to this unprecedented educational change? How to captivate students in these technological times?

Aligned with this thought and in the light of the need to answer the current academic and professional demands of the sector, the challenge to implement a training program for higher education in the context of a new undergraduate and graduate specialization 
in Event Organization, Protocol and Institutional Relations was set. Specifically, in the first installment of the compulsory subject in the fourth academic year called New Technologies Applied to Events, and the redesign of the core subject of the Master's degree Communicative skills, empowerment and personal branding: Managing Large Events. This program would be oriented, by means of a participative methodology of teaching-learning learning by doing, to provide students with the capacity to understand, internalise and apply professionally cross-sectional knowledge and skills on technology in the communication and organization of events, from the creation of their personal brand as an instrument of digital literacy and professional empowerment.

Personal branding is today a core element in the management of a professional career for communication professionals (Del Toro, 2015). It constitutes a distinctive and demonstrable value of knowledge, maturity and responsible use of social media, and goes beyond the construction of digital identity, understood as the "ability to manage successfully one's own online visibility, reputation and privacy, as an indivisible and fundamental component of all information and digital skills" (Giones \& Serrat, 2010, par. 4), with, in addition, a multidimensional and hybrid character, originated from the convergence between analogical and virtual identity (Castañeda \& Camacho, 2012). Personal branding "implies the positioning, differentiation and values that a person projects and builds up in their environment via interactions, acts, use of social media, etc." (Del Toro, 2015, p. 15) and is expressed throughout its digital imprint (Arda \& Fernández, 2012; Pérez-Ortega, 2014; Schawbel, 2011). This approach has allowed favouring active participation of students in their training, stimulating autonomous and informal learning, and improving their employability opportunities and professional development.

\section{CASE AND STUDY METHODOLOGY}

This paper presents the results of the training program, and aims to demonstre novel teaching routes for teaching methodologies in higher education geared towards the reinforcement of employability of graduates, by means of a process based on resignification of educational e-innovation that stimulates among students the capacity of systemic, strategic and dialogic thinking about the relation between technology, communication and labour market.

\subsection{Case description}

This is a research-action training experience, "as a way to understand education and not only to inquire in it" (Romera-Iruela, 2011). This very case evolves into research-action due to its communicational and "participative research-intervention-observation" nature as a result of progressive development cycles during the semester. A study problem is defined by the "rethought" didactic usage of technology in the learning teaching relation. In this direction, aiming at guiding the study, two hypotheses are presented, as follows. H1. Students perceive themselves as widely familiar with social media, although a personal use prevails; and $\mathrm{H} 2$. Teaching innovation based on the resignification of the use of technology in teaching can motivate the student to unlearn and learn to learn about managing their professional digital identity, improving their skills for job placement and entrepreneurship.

Specifically, in this case a teaching guide tailored to each subject has been designed, and students are encouraged to engage in the challenge of managing their personal brand during the course. They take as a starting point the content provided in class, assignments in each teaching unit, internalisation exercises and group dynamics, collaborative learning and exchange of experiences, which would enable as a whole favouring job placement of their professional profile in the professional specialization area of Event Organization, Protocol and Institutional Relations. To this end, the main activities that have been developed are those shown in the Figure 1.

\subsection{Evaluation methodology for the case study}

In order to carry out the evaluation of the training program that was applied, a non-experimental ex post-facto research methodology
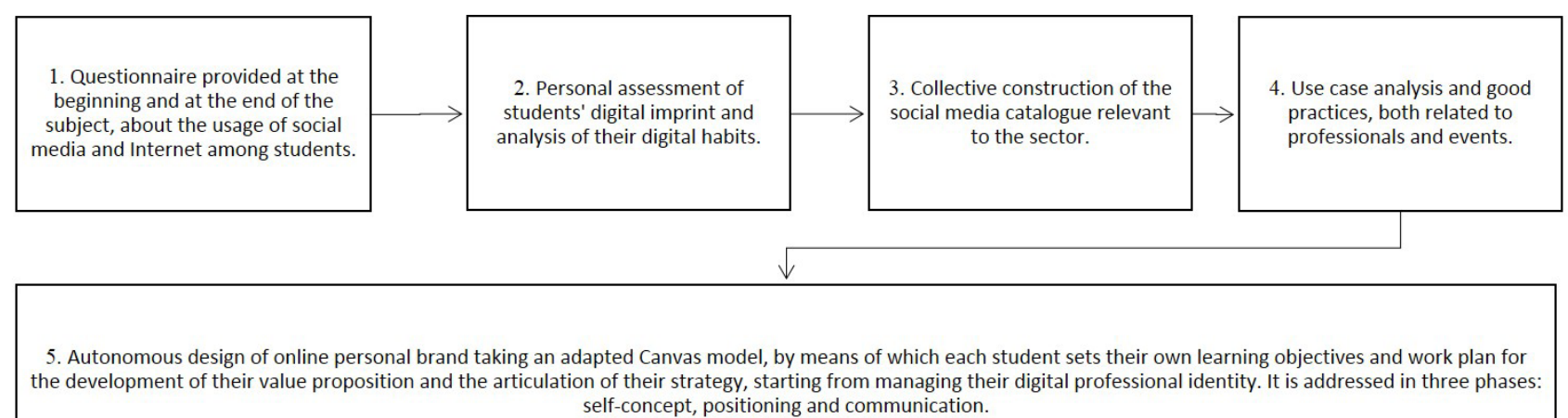
the development of their value proposition and the articulation of their strategy, starting from managing their digital professional identity. It is addressed in three phases: self-concept, positioning and communication.

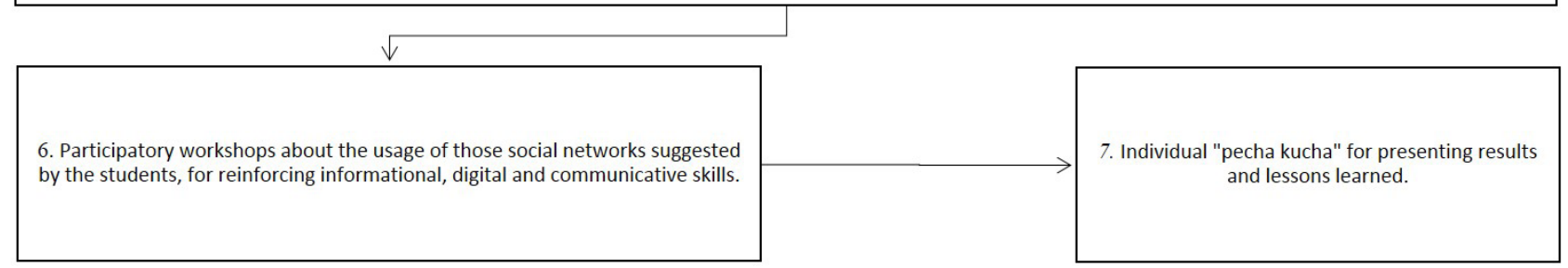

Figure 1. Activities program developed in the target subjects 
was developed. The reason for this choice was the impossibility to manipulate independent variables. Also, random allocation of subjects and treatment or stimulus (training program) was not intended (Hernández-Sampieri, Fernández-Collado, \& Baptista, 2014), and hence all the students became participants in the study. A longitudinal prospective study was designed and applied twice over the population under analysis. This was due to our goal to assess the possible changes produced in this population, considering that this is the only non experimental design that has a certain resemblance to an experimental one, and allows determination of potential causal relations among variables (Díaz de Rada, 2007). However, the object of study is also addressed from an exploratory and cross-sectional descriptive perspective.

The technique used was a panel-type survey, since we used the same universe and sample in both iterations (Hernández-Sampieri et al., 2014).

As a measuring instrument, two ad-hoc questionnaires were designed: A base questionnaire for the first iteration, and an extended one for the second one, in the terms indicated by Díaz de Rada, so that it would be possible to introduce questions in additional waves to obtain more information about the subjects (2007, p. 141).

The initial questionnaire features three main blocks of questions: a) one referred to the sociodemographic data of the participants, as well as their familiarity with ICT and available technologies; b) a second block centered on how students use social media; and c) finally, a third block containing questions concerning the students' expectations on the training program to be applied. The questionnaire of the second iteration is extended with two additional blocks: d) one of them, for determining changes produced in the use of social media and management of personal brands after attending the training program; e) and a final one which attempts to assess the fulfillment of initial expectations and the degree of satisfaction with different aspects of the program.

Both questionnaires include closed and semi-open questions, which allow single and multiple answers. In addition, scales of assessment have been included to determine the degree of satisfaction with the training experience. Finally, a set of open questions have been introduced, in an exploratory manner, in order to obtain qualitative and wide information about the expectations of the students and about the obtained results, as this was the first time in which the program was developed, and no prior knowledge about these variables existed.

The study was carried out among the students of the Mediterranean Institute of Protocol Studies (a centre associated to the Miguel Hernández University of Elche), who during the academic year 2015-16 studied the fourth year in their degree, or the Master's course in the specialization of Event Organization, Protocol and Institutional Relations, in the subjects mentioned above. Specifically, the study population or universe was the 24 undergraduate students and the 11 graduate students of this edition. All students were interviewed, which prevents random sampling error caused by selecting a population sample (Hernández-Sampieri et al., 2014). The obtained data has been treated with univariate and bivariate descriptive analyses, according to the degree of measurement of variables (frequencies, percentages and measures of central tendency for univariate analysis; and contingency tables and variance analysis - ANOVA - for bivariate).

As an independent variable, the current degree being studied was mainly considered (degree or MA). In addition, additional analyses were carried out considering other variables like gender, age and level of initial knowledge. However, due to the limited number of case studies and the homogeneity of the population (for example, most of the students are women, except 3 undergraduate students and one postgraduate; and concerning age, the trend persists, with $88 \%$ of the students being in an age range of 21-25 years old), difficulties to find significant differences were foreseen, as it is shown in the following section.

\section{RESULTS}

Almost all of the students in both degrees pointed out that this training program could improve their employability opportunities in the future (except one undergraduate case), and this was confirmed again upon completion of the course, in alignment with one of its main goals. They believed that this would be mainly due to two reasons: a) because an increasing number of companies and employers use new technologies and social media for their selection processes, either for searching for candidates or for their evaluation, making it indispensable to have an appropriate personal brand; and b) in the work environment it is crucial to have a wide range of skills and knowledge on digital tools for carrying out almost any task, especially in the knowledge area we are concerned with, closely related with communication.

As for the level of knowledge in personal/professional learning environments, initially only $43 \%$ of students showed awareness of this, specifically $42 \%$ in undergraduate (10 cases) and $45 \%$ in postgraduate level (5 cases), although these differences are not statistically significant $(\mathrm{C}=0.336$; $\mathrm{Sig} .=0.833)$. Upon completion of the educational program, all the students confirmed that they had extended their knowledge with respect to this issue.

On the other hand, it is also possible to observe how the perception about the degree of user-level knowledge, in both cases, has changed from the beginning of the activity until its end, although without significant differences $(\mathrm{C}=0.042$; $\mathrm{Sig} .=0.803)$. At the beginning of the course, $6 \%$ ( 2 cases, both undergraduate), considered they had an introductory level, 60\% (21 cases, 17 undergraduate and 4 postgraduate) had an intermediate level, and the remaining 34\% (12 cases, 5 undergraduate and 7 postgraduate), an advanced level. At the end of the program, 51\% (18 cases, 12 undergraduate and 6 postgraduate) estimated that their final level was intermediate, and 49\% (17 cases, 12 undergraduate and 5 postgraduate) had achieved an advanced level.

At the beginning of the training experience most of the students of both courses used online resources for activities related with their personal environment $(86 \%)$, studies $(83 \%)$, and leisure and culture $(77 \%)$ with no significant degree-wise differences $(C=0.473$, Sig. $=0.182$ ). As a result of the training program, it was found that the personal usage persists, but use for professional or work-related activities has increased, as can be seen in the Figure 2.

With regard to the above, we can also see certain changes in the use of digital resources in certain specific aspects (see Figure 3). For instance, in the labour market dimension there is an increase from $45 \%$ to $71 \%$ (from 16 to 25 cases), in job seeking from $49 \%$ to $77 \%$ (from 17 to 27 cases), the use of finance resources from $9 \%$ to $49 \%$ (from 3 to 17 cases), or in conducting research of topics of interest, from $29 \%$ to $35 \%$ (from 10 to 12 cases). As an additional illustrative example, let us mention that searching for new professional contacts via social media went from $46 \%$ of the students to almost all of them (92\%, from 16 to 32 cases), or when it came to finding contacts for entrepreneurship, where the increase was from $9 \%$ to $43 \%$ (from 3 to 15 cases). 


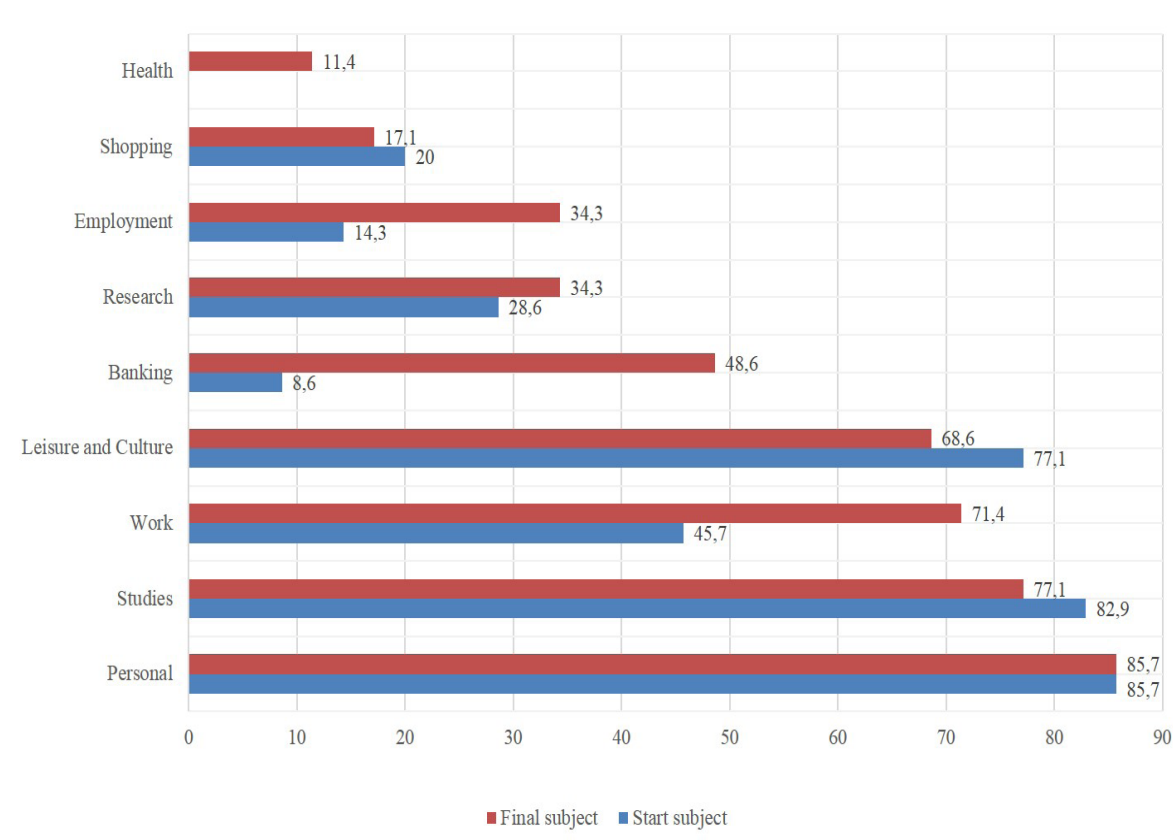

Figure 2. A general comparison of the degree of usage of digital resources between the beginning and end of the subjects (\%)

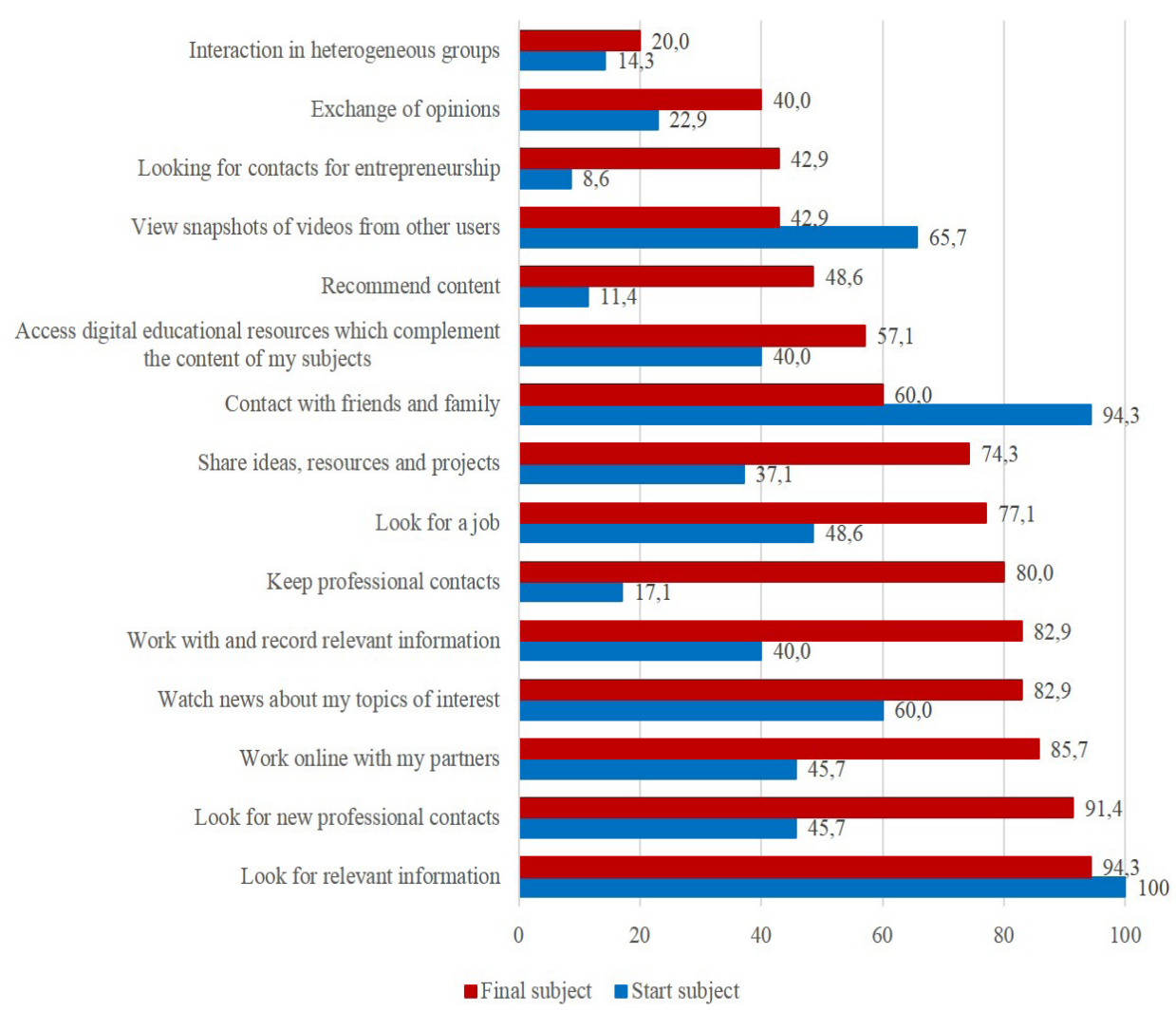

Figure 3. Comparison of the specific usage of digital resources between the beginning and completion of the subjects (\%) 
With regard to the use of online media used for consulting information and digital content, before and after this training experience, we can also see a notable change in both degrees $(\mathrm{C}=0.447$; Sig. 0.849). The most utilized media before the course started were, in order: Social networks ( $86 \%, 30$ cases), general search engines ( $80 \%, 28$ cases), web pages $(66 \%, 23$ cases) and blogs $(60 \%, 21$ cases). Upon completion of the training program, there is an increase in the use of social networks and web pages up to $97 \%$ and $83 \%$ respectively, while the use of general search engines and blogs decreases slightly ( $77 \%$ and $71 \%$ respectively), thus favouring more specific media. This means that the use of email almost doubles (from 12 to 22 cases), there is a relevant increase in the use of specialized search engines, going from $14 \%$ to $40 \%$ (from 5 to 14 cases), the search in digital newsletters grows from $23 \%$ to $37 \%$ (from 8 to 13 cases), 12 students start using for the first time RSS management systems, and finally there is first-time virtual community participation by $17 \%$ ( 6 cases) of the students.

Before the beginning of the course, almost all students in both specializations had a personal space on the Internet (except one undergraduate case), but this was centered on social media (97\% of the students), and to a lower degree on blogs (14\%, 5 cases). None of them had their own website. The influence of this program can be seen in that up to $17 \%$ (6 cases, 4 undergraduate and 2 graduate) of the students built their own website upon completing the course, and $51 \%$ (18 cases, 8 undergraduate and 10 graduate) now also have a blog.

The main expectations of the students, analyzed qualitatively, were centered mainly on acquiring a wide knowledge of online resources, as well as the opportunities for developing an appropriate personal and professional brand in social media, among others which we list as follows.

- Delving into social media interaction, and learning about different applications and online resources for a better work-related performance, specifically in the event management sector (14 mentions by undergraduate students, 8 graduate).

- Learning to create an interesting and remarkable profile for the future, i.e. a unified personal and professional image appropriate to be leveraged in prospective projects ( 8 mentions by undergraduate students and 4 graduate).

- Being able to assess online reputation (3 mentions by undergraduates, 2 by graduate students).

- Attending a practical subject enabling students to internalise knowledge and ease up its application ( 5 mentions by undergraduates and 3 by graduate students).

- Acquiring knowledge to develop personal and professional projects in the future by means of online resources and tools ( 2 undergraduate mentions, and 1 graduate).

- Improving teamwork ( 2 mentions by undergraduates).

The analysis of lessons learned shows a relevant evolution in the knowledge and usage of virtual resources with respect to the initial expectations, which seem to be confirmed by the statements we provide next (obtained from codifying and counting literal answers to this question).

- Having obtained a profound and wide knowledge about a great number of digital tools, especially in those that participants were unaware of (19 mentions by undergraduates, 8 by graduate students).

- Understanding how to leverage social media and online applications in a work environment (10 mentions by undergraduates, 7 graduates).

- This subject and its didactic methodology has helped to clarify the desired professional profile, and the line of work to be followed, based on a previous consideration ("It has helped us to grow personally and professionally"), (10 mentions in the undergraduate course).

- Successfully building/designing an appropriate virtual image. Understanding the importance of the image one projects on the Internet, and the need to combine it with security and professionalism (24 undergraduate mentions, and 11 at graduate level).

- The opportunity to put into practice theoretical content learned in class (12 undergraduate and 3 graduate mentions).

- Development of novel elements related to one's virtual image: blogs, websites, etc. ( 8 undergraduate and 8 graduate mentions).

- Improving the use of tools for job searching (7 undergraduate and 5 graduate mentions).

- Searching for novel online sources of knowledge (5 undergraduate and 3 graduate mentions).

- Knowledge of tools for selective and quick search of information ( 8 mentions by undergraduates, 5 by graduates).

On the other hand, as it is shown in Table 1, the overall average assessment of this training program was of 6 out of 7 points, which shows a high level of satisfaction which, in addition, is similar across both degrees.

Table 1. Level of satisfaction with the training program

\begin{tabular}{lccccc}
\hline $\begin{array}{c}\text { Assessment } \\
\text { and ANOVA } \\
\text { values } \begin{array}{c}\text { (scale } \\
\text { from 1 to } \\
\text { points) }\end{array}\end{array}$ & $\begin{array}{c}\text { Undergra- } \\
\text { duate }\end{array}$ & $\begin{array}{c}\text { Gra- } \\
\text { duate }\end{array}$ & Total & F & Sig. \\
\hline $\begin{array}{l}\text { Informational } \\
\text { skills }\end{array}$ & 5,2 & 5,9 & 5,4 & 2,529 & 0,121 \\
\hline Self-concept & 5,0 & 5,9 & 5,3 & 4,581 & 0,040 \\
\hline Value proposal & 5,8 & 6,1 & 5,9 & 0,304 & 0,585 \\
\hline Usability & 5,9 & 6,3 & 6,0 & 0,807 & 0,376 \\
\hline Optimization & 5,7 & 6,3 & 5,9 & 1,550 & 0,222 \\
\hline $\begin{array}{l}\text { Digital } \\
\text { Marketing }\end{array}$ & 5,4 & 6,1 & 5,6 & 2,647 & 0,113 \\
\hline General & 6,0 & 6,2 & 6,0 & 0,550 & 0,463 \\
assessment & & & & & \\
\hline Source: Own preparation. & & & & & \\
\hline
\end{tabular}

The levels of satisfaction with the rest of the elements proposed in the assessment were also high, with scores beyond 5 and 6 points in most cases. The lowest scoring cases were those related with "informational skills" and the "self-concept". The average assessment by graduate students is slightly higher, albeit not statistically significant.

Finally, students were asked about potential "areas for improvement" in the training program. Given the high degree of satisfaction they showed, most of them were fine with the course's structure and organization, although there were a few suggestions which we detail as follows: 
- Setting up personalized office hours for supporting the students' self development ( 2 undergraduate mentions, and one at graduate level).

- A widening of content so that it applies directly in the specific knowledge area: Event Organization (7 undergraduate mentions and 2 at graduate level).

- The option to provide deeper insights on the main tools. (4 mentions by undergraduates).

- Providing further details about website development and their use (3 undergraduate mentions and 1 at graduate level).

These results show how, with this experience, a high degree of satisfaction among students has been obtained, surpassing their own expectations. In general, students have successfully become more familiar with the main online tools for attaining an optimal personal and professional development.

\section{DISCUSSION AND CONCLUSIONS}

The findings provided here seem to confirm the hypotheses set at the beginning of this research. First, these results show that these digital natives as understood by Prensky (2001), who have grown up surrounded by technology as an inherent part of their daily life, make it a prominently personal use, which highlights their own limitations. Thus, it seems to be necessary to develop educational strategies based on media autonomy, as pointed out by Gozálvez and Aguaded (2012). These, in addition to invigorating the motivation of students for learning by setting up autonomous objectives and application of participatory educational strategies, foster critical thinking and the development of professional skills in today's knowledge society (Fernández, Cabreiro, \& Fernández, 2010). Secondly, applying teaching innovation strategies based on the resignification of technological uses has enabled students to become aware of their digital imprint (Pérez-Ortega, 2014), and to rethink the personal use they make of digital technologies, for guiding their professional digital identity (Castañeda \& Camacho, 2012) towards the professional profile with which they would like to enter the job market via their personal brand (Del Toro, 2015).

Hence, these findings suggest that it is possible to motivate the participation of students via a balanced and rethought use of technologies, at the service of education, as Namo (2005) suggested, and where the relation teaching-learning stops being a separate action of teachers and students, according to Abraham (2004) in favour of becoming collaborative learning environments (UNESCO, 2015). Balance and motivation are achieved in this work prioritizing, on one hand, a topic in which students are profoundly interested, namely job placement, so that they become protagonists and individuals responsible for their own future, empowering them; and on the other, showing awareness of teaching vocation in terms of good teaching as suggested in Porta and Sarasa (2014). In this way, the case hereby presented makes it possible to conclude that showing confidence in the capacities of students for self learning, as was suggested by López and Miró (2014), has as a result digital autonomy, according to the digital skills map proposed by Ferrari (2013). It was also possible to verify that they were capable to reinforce their personal brand as future professionals, thanks to a training program based on what we could call digital re-literacy, as an expression of educational e-innovation resignification. It should be considered, in addition, that thanks to the cognitivist pragmatism by authors like Sobrino (2011), we understand that knowledge is negotiated throughout experience and thought, and consequently, teaching efforts must be centered on helping students to create personal meanings by means of experience, as it was the goal in this case.

In summary, the didactic strategy followed in the design of this training program from a resignification perspective in the role of the teacher as a guide, and not as a content manager in this technological era, according to Cobo's thesis (2016), has achieved important goals such as the following: It has favoured active participation of students in their training, has motivated autonomous and informal learning, has promoted responsible use of social media (OCDE, 2015) and, as a consequence, has improved their employability and development opportunities in the areas of Event Organization, Protocol and Institutional Relations. This aligns with previous experiences in higher education (Maxwell, Irwin, \& Bennett, 2015; Rivers, 2016; Teixeira, Albino, \& Oom, 2015).

The importance of favouring employability opportunities of graduates from a resignification of educational e-innovation becomes apparent inasmuch, as the results of the evolution during the semester are analyzed, we can see that students develop a critical vision of the technological environment (Gozálvez \& Aguaded, 2012), as well as a skill for thinking systemically, strategically and dialogically, as mentioned in Avargil et al. (2012), Asiya et al. (2016) and Hajhosseiny (2012), respectively. An emancipatory perspective from which they design, implement and manage their own social media aimed at job placement, specialization of professional profile, and their incorporation to the job market, as we can observe when comparing their initial self perception about the use of technologies and social media with the lessons learned and abilities acquired at the end of the semester. Qualitative evaluation, moreover, on the satisfaction with the program, provides testimonies that may represent theses from neuroeducation by Mora (2013) and Forés (2012), who reflect on the role of emotion and e-emotion respectively in education.

Lastly, the presented results encourage us to widen this study to larger groups and to extend this experience to new teaching programs in other university degrees.

\section{LIMITATIONS, IMPLICATIONS AND FUTURE RESEARCH DIRECTIONS}

The limitations of this work stem mainly from the specific and reduced universe of the study, although it was necessary for setting up the starting point of such specific and relevant research, based on two main considerations. First, to account for the specificity of the new degree and Master's degree on Event Organization, Protocol and Institutional Relations, and on the other hand, for the challenge to investigate about resignification in educational e-innovation. The number of research works on educational e-innovation and its interaction with technology is still scarce. The results reported in this paper, while modest, present interesting implications with respect to the models of educational innovation, not only for transferring knowledge to students, and training them in skills, but also as Mora (2013) affirmed, to assess and improve the preparation of those who teach and help and facilitate the process of those who learn, and in parallel, to construct a professional digital identity or personal brand both for the student and the teacher. We expect future lines of research to open in the application of these findings to different areas of knowledge and different professional profiles, as well as deepening in the resignification of the concept of educational e-innovation, prioritizing good pedagogy and looking at generational, cultural, functional and intellectual diversity. 


\section{REFERENCES}

Abraham, M. (2004). La resignificación de los procesos de enseñanza y aprendizaje de alumnas y alumnos de formación docente inicial. Pensamiento Educativo, 35(2), 216-234.

Adell, J., \& Castañeda, L. (2013). El ecosistema pedagógico de los Entornos Personales de Aprendizaje: Claves para el ecosistema educativo en red. Alcoy: Marfil.

Aguaded, J. I., \& Tirado, R. (2008). Los centros TIC y sus repercusiones didácticas en primaria y secundaria en Andalucía. Educar, 41, 61-90.

Arda, Z., \& Fernández, C. (2012). Social media, autoimagen e imagen de la marca. adComunica, 3, 231-234. doi:10.6035/2174-0992.2012.3.19

Asiya, S., Naaranoja, M., Kytola, J., \& Kantola, J. (2016). Connecting strategic thinking with product innovativeness to reinforce NPD support process. Procedia - Social and Behavioral Sciences, 235(24), 672-684.

Avargil, S., Herscovitz, O., \& Dori, Y. J. (2012). Teaching thinking skills in context-based learning: teachers' challenges and assessment knowledge. Journal of Science Education and Technology, 21(2), 207-225. doi:10.1007/s10956-0119302-7

Campos, G., \& Fuente, C. (2013). Los eventos en el ámbito de la empresa. Hacia una definición y clasificación. Revista de Comunicación de la SEECI, 32, 73-105. doi:10.15198/seeci.2013.32.73-105

Cano, E. (Ed.). (2012). Aprobar o aprender. Estrategias de evaluación en la sociedad red. Barcelona: Laboratori de Mitjans Interactius (UB). Retrieved from https://goo.gl/lkFCh5

Carlsson, U., Tayie, S., Jacquinot Delaunay, G., \& Pérez Tornero, J. M. (2008). Empowerment through media education. An intercultural dialogue. Nordicom-Göteborg University: Göteborg.

Castañeda, L., \& Camacho, M. (2014). Desvelando nuestra identidad digital. El profesional de la información, 21(4), 354-360. doi:10.3145/epi.2012.jul.04

Cobo, C. (2016). La Innovación Pendiente. Reflexiones (y Provocaciones) sobre educación, tecnología y conocimiento. Montevideo: Debate. Retrieved from https://goo.gl/EfGyLZ

Cobo, C., \& Moravec, J. W. (2016). El aprendizaje invisible. Col·lecció Transmedia XXI. Barcelona: Laboratori de Mitjans Interactius (UB). Retrieved from https:// goo.gl/ss $68 \mathrm{~Eb}$

Davies, D., Jindal, D., Collier, C. Digby, R., \& Hay P. (2013). Creative learning environments in education $-\mathrm{A}$ systematic literature review. Thinking Skills and Creativity, 8, 80-91. doi:10.1016/j.tsc.2012.07.004

De Abreu, B., Mihailidis, P., Lee, A. Y. L., Melki, J., \& McDougall, J. (2017). International Handbook of media literacy education, 1-415.

De Andrade, L. M., \& Lacerda G. (2014). Cibercultura e mediaçäo pedagógica: Estudo acerca da inclusäo digital docente. En C. A. Rosa \& G. Lacerda (Eds.), $A$ inclusão digital em meios de ensino formais e não-formais (pp. 5-33). Lisboa: FMH edições.

Del Toro, A. (2015). Marca personal en medios sociales digitales: propuesta de modelo de autogestión (Doctoral dissertation). Madrid: Universidad Complutense de Madrid.

Díaz de Rada, V. (2007), Tipos de encuesta considerando la dimensión temporal [Longitudinal research and survey research]. Papers, 86, 131-145. doi:10.5565/ rev/papers/v86n0.814

European Union (2017). DigComp 2.1: The Digital Competence Framework for Citizens with eight proficiency levels and examples of use (Report). Luxemburg: Publication Office of the European Union.

Fernández, C., Cabreiro, B., \& Fernández, C. (2010). Competencias para el aprendizaje en red de los alumnos de educación secundaria en Galicia. Pixel-Bit, 38, $7-21$

Ferrari, A. (2013). DIGCOMP: A framework for developing and understanding digital competence in Europe. Sevilla, España: Institute for Prospective Technological Studies.

Forés, A. (2012). E-emociones. Sin emoción no hay educación. Tendencias emergentes en educación con TIC. Barcelona: Asociación Espiral, Educación y Tecnología.

Giones, A., \& Serrat, M. (2010). La gestión de la identidad digital: una nueva habilidad informacional y digital. $B i D, 24$.

Gozálvez, V., \& Aguaded, J. (2012). Educación para la autonomía en sociedades mediáticas. Anàlisi: quederns de comunicación i cultura, 45 (1-14).

Gutiérrez, A., \& Torrego, A. (2017). The Twitter games: media education, popular culture and multiscreen viewing in virtual concourses. Information, Communication \& Society Review, 2, 1-14.

Hajhosseiny, M. (2012). The Effect of Dialogic Teaching on Students' Critical Thinking Disposition. Procedia - Social and Behavioral Sciences, 69(24), 13581368. doi:10.1016/j.sbspro.2012.12.073

Hernández-Sampieri, R., Fernández-Collado, C., \& Baptista, P. (2014). Metodología de la investigación, $6^{\mathrm{a}}$ Ed., México: McGraw Hill.

Herrero, J., \& Perelló Roselló, M. (2017). La enseñanza del protocolo y la organización de eventos en el espacio europeo de educación superior: análisis comparado de los planes de estudio. Estudios sobre el Mensaje Periodístico, 23 (1), 437-455. doi:10.5209/ESMP.55606
López, D., \& Miró, J. (2014). Creencias que merecen una reflexión. ReVisión, 7(3), 61-68.

López, L., \& Aguaded, M.C. (2015). Teaching media literacy in colleges of education and communication. Comunicar, 22(44), 187-195. doi:10.3916/C44-2015-20

Mair, J., \& Whitford, M. (2013). Special issue on event and festival research methods and trends. International Journal of Event and Festival Management, 4(1), 210-217. doi:10.1108/ijefm.2013.43404aaa.001

Maxwell, R., Irwin, W., \& Bennett, S. (2015). When education met innovation met employability: The birth of employability plus. 14th European Conference on e-Learning. University of HertfordshireHatfield, United Kingdom.

Mishra, P., \& Koehler, M. J. (2006). Technological pedagogical content knowledge: A framework for teacher knowledge. Teachers College Record, 108(6), 1017 1054. doi:10.1111/j.1467-9620.2006.00684.x

Mihailidis, P. (2015). Digital curation and digital literacy: evaluating the role of curation in developing critical literacies for participation in digital culture. E-learning and Digital Media, 12, 5-6. doi:10.1177/2042753016631868

Mitra, S., Kulkarni, S., \& Stanfield, J. (2016). Learning at the edge of chaos: Self-organising systems in education. In H. E. Lees \& N. Noddings (Eds.), The Palgrave International Handbook of Alternative Education (pp. 227-239). London, UK: Palgrave Macmillan. doi:10.1057/978-1-137-41291-1_15

Mora, F. (2013). Neuroeducación. Madrid: Alianza editorial.

Moreno, N. M., \& Vera, J. (2012). Herramientas TAC al servicio de los procesos de enseñanza y aprendizaje del español como segunda lengua (L2) en las ATAL. Congreso Iberoamericano de las Lenguas en la Educación y en la Cultura, IV Congreso Leer.es. Organización de Estados Iberoamericanos para la Educación, Salamanca. Retrieved from https://goo.gl/FJuEqn

Morín, E. (1999). Los 7 saberes necesarios para la educación del futuro. París: Santillana.

Namo, G. (2005). Profesores para la igualdad educacional en américa latina. Calidad y nadie de menos. Prelac, 1, 25-37.

OCDE (2015). Students, Computers and learning: making the connection. doi:10.1787/9789264239555-en

Otero, M. T. (2002). Teoría y estructura del ceremonial y el protocolo. Sevilla: Mergablum Edición y Comunicación.

Pérez-Ortega, A. (2014). Marca personal para dummies. CEAC.

Pineda, R. (2002). La resignificación de la realidad a la luz de la innovación tecnológica. Abra, 22(31), 113-118

Porta, L. G., \& Sarasa, M. C. (2014). Resignificar la buena enseñanza desde la voz de docentes memorables en educación superior confrontada con Ortega y Gasset $\mathrm{y}$ otros académicos [Rethink the good teaching from the voice of memorable teachers in higher education in discussion with Ortega y Gasset and other academics]. Profesorado, 18(1), 293-306.

Prensky, M. (2001). Nativos digitales, inmigrantes digitales. On the Horizon, 9(5), 1-7. doi:10.1108/10748120110424816

Ricaurte, P. (2016). Pedagogies for the open knowledge society. International Jour nal of Educational Technology in Higher Education, 13. doi:10.1186/s41239016-0033-y

Richards, G. (2017). From place branding to placemaking: the role of events. International Journal of Event and Festival Management, 8(1), 8-23.

Richards, G., Marques, L., \& Mein, K. (2014). Event design: Social perspectives and practices. New York: Routledge. doi:10.1108/IJEFM-09-2016-0063

Reig, D. (2012). Disonancia cognitiva y apropiación de las TIC. Telos, 90(1), 9-10.

Rivers, A. (2016). Social innovation education: Designing learning for an uncertain world. Advances in Digital Education and Lifelong Learning, 2, 75-90. doi. org:10.1108/S2051-229520160000002004

Sancho, J. M. (2008). De TIC a TAC, el difícil tránsito de una vocal. Investigación en la Escuela, 64, 16-30.

Sardelich, M. E. (2012). TIC/TAC/TEP: Tecnologías para empoderar e aprender. UNISANTA Humanitas, 1(1), 22-31.

Schawbel, D. (2011). Yo 2.0. 4 pasos para conquistar el futuro. Spain: Conecta.

Siemens, G. (2006). Knowing Knowledge (eBook). Retrieved from http://goo. $\mathrm{gl} / 2 \mathrm{hWt}$

Sobrino, A. (2011). Proceso de enseñanza-aprendizaje y web 2.0: valoración del conectivismo como teoría de aprendizaje post-constructivista. Estudios sobre educación, 40, 117-140.

Simpson, A. (2016). Designing pedagogic strategies for dialogic learning in higher education. Technology, Pedagogy and Education, 25(2), 135-151. doi:10.1080/ 1475939X.2015.1038580

Strongoli, R. (2014). New education and active school in Europe in the early 20th century. Models, themes and figures. History of Education and Children's Literature, $9(2), 813-822$.

Teixeira, S., Albino, J., \& Oom, P. (2015). A model of graduates' satisfaction and loyalty in tourism higher education: The role of employability. Journal of Hospitality, Leisure, Sport \& Tourism Education, 16, 30-42. doi:10.1016/j.jhlste.2014.07.002

UNESCO (2015). Replantear la educación: ¿hacia un bien común mundial? Retrieved from http://goo.gl/ZKlfbF 
USC (2016). Global Communications Report 2016. Retrieved from https//goo.gl/ bCmmel

Vygotsky, L. S., Luria, A. R., \& Leontiev, A. N. (1988). Linguagem, desenvolvimento e aprendizagem. São Paulo, Brasil: Ícone.

WEF (2016). The Future of Jobs Employment: Skills and Workforce Strategy for the Fourth Industrial Revolution. Global Challenge Insight Report. Retrieved from https://goo.gl/hApzcP

Xuan, H., \& Xioameng, W. (2015). A Study on the Factors Influencing Media Literacy among Youth Students. In 2015 International Conference of Educational Innovation through Technology. China. doi:10.1109/EITT.2015.70

How to cite this article: Torres Valdés, R. M., Santa Soriano, A., Lorenzo Álvarez, C. (2018). Resignification of educational e-innovation to enhance opportunities for graduate employability in the context of new university degrees. Journal of New Approaches in Educational Research, 7(1), 70-78. doi: 10.7821/naer.2018.1.263 